\title{
The contribution of participatory budgeting to the achievement of the Sustainable Development Goals: lessons for policy in Commonwealth countries
}

\section{Commonwealth Journal of Local Governance}

Issue 21: December 2018

http://epress.lib.uts.edu.au/ojs/index.php/cjlg

\author{
Yves Cabannes \\ Bartlett Development Planning Unit \\ University College London \\ United Kingdom \\ Email: y.cabannes@ucl.ac.uk
}

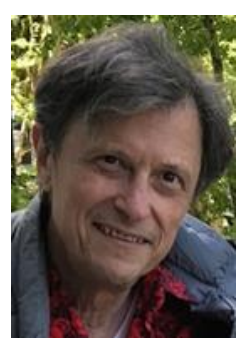

\begin{abstract}
After briefly defining participatory budgeting and reviewing its evolution worldwide and Commonwealth expansion over the last three decades, this paper explores the potential it holds for contributing to the achievement of the United Nations' Sustainable Development Goals. Its looks especially at how participatory budgeting is contributing to the achievement of SDG 16 and provides some specific recommendations for action, based on innovative practice examples from around the world, highlighting how practice across diverse local authorities could be used to monitor target 16.7 'to ensure responsive, inclusive, participatory and representative decision-making at all levels.'
\end{abstract}

\section{Introduction}

After a brief definition of participatory budgeting (PB), and a short exploration of its evolution and worldwide expansion over the last three decades, with a particular focus on Commonwealth countries' PB experiences, this paper explores the contribution PB is, and can, make towards achieving the UN's Sustainable Development Goals (SDGs). Using exemplary experiences from diverse local authorities, the paper highlights how and to what extent local PB initiatives meet SDG targets and implement crosscutting principles, particularly that of 'leaving no one behind'. It argues that PB as a distinct and inclusive form of citizen engagement in public decision-making worldwide, primarily contributes to the achievement of SDG 16 "To promote peaceful and inclusive societies for sustainable development, provide access to justice for all and build effective, accountable and inclusive institutions at all levels", especially its potential to help countries meet SDG Target 16.7 "To ensure responsive, inclusive, participatory and representative decision-making at all levels" (UN 2015) through their local authorities. Based on lessons drawn from extensive observation of PB practices, the concluding section suggests eight recommendations to strengthen local government capacities to use PB to achieve SDG 16. It concludes that PB could be a useful indicator to monitor SDG target 16.7. 


\section{Evolution and expansion of PB over the last three decades}

Participatory budgeting is, at its core, a form of decision-making that actively involves citizens in prioritising spending of public resources. ${ }^{1}$ It can be defined as follows: a mechanism or a process through which people make decisions on the destination of all or a portion of the public resources available, or are otherwise associated with the decision-making process. Within this general definition, PB experiments span a broad spectrum: from symbolic participatory gestures with little transformative impact, to vectors of structural change in cities' governance systems. The latter, this paper argues, have reconfigured relationships and responsibilities among actors and institutions in the public domain - and have led to measurable improvements in the quality of life of citizens (Cabannes and Lipietz 2018).

\section{Four phases of PB evolution and expansion}

The first phase, typically seen as 1989 to 1997, was a period of experimentation: starting in Porto Alegre, Brazil, and a few other cities (Santo André in Brazil and Montevideo in Uruguay), new forms of participatory and representative decision-making on public resource allocation were literally 'invented'. This was followed by a "Brazilian spread", when more than 130 Brazilian municipalities adopted the model, albeit with marked variations (Cabannes 2003). With the new millennium came a second stage of expansion beyond Brazil and a third of diversification, with existing models being profoundly adapted (Cabannes 2003). Over this time, PB spread throughout Latin America and to Europe and, since 2003, Africa. Over the decade since 2010, a phase of consolidation can be observed, as PB activities expand in all regions of the world, with a noticeable spread in Asian and Russian local and regional governments, and Arab and North American and Pacific cities being the latest newcomers to the fold.

\section{A major innovation in participatory governance worldwide}

PB has been a major innovation in participatory governance worldwide, with more than 6,000 experiences listed across at least 40 countries in $2019 .^{2}$ This is a conservative estimate and has some notable features: a) great regional differences, with for instance quite a limited number of experiences from the Caribbean and Pacific island nations compared to Latin American or African countries; b) a very high number of experiences in a few countries, such as those with national laws on compulsory PB at local government level; ${ }^{3}$ or at both local and regional government level ${ }^{4}$ - which have resulted in over 2,600 'official' cases in these countries alone; c) a very swift spread across some countries that makes monitoring difficult: for example in Russia where PB expanded to over 50 of its 85 federal regions in just a couple

\footnotetext{
1 The author would like to thank the UCLG GOLD V team for helpful comments on an earlier version of this paper and the opportunity to feed into the 2019 Report of Local and Regional Governments to the High-Level Political Forum (GTF 2019).

${ }^{2}$ List compiled by the author over the past three decades.

${ }^{3}$ South Korea LocalFinance Act 2011, Article 39 and Enforcement Ordinance 2011, Article 46. Dominican Republic Law 2009 170-07, instituted a system of participative participatory budgeting now mandatory for municipalities.

${ }^{4}$ Peru Law No. 280562003 which is a framework law on participatory budgeting ('Ley marco de presupuesto participativo y su reglamento').
} 
of years (Shulga et al. 2017), or in Indonesia where the enactment of the Village Law 2016 opened up the possibility of PB in the country's 73,000 villages. The overall message, which is of direct interest for the achievement of the SDGs, is that over the coming decade the number of countries where local governments are practising PB will continue to expand. This universalisation of PB practices leads us to argue that this evidenced body of 'inclusive, participatory decision-making' should be taken much more into account in national planning processes and in national reporting against the SDGs.

\section{Three decades of substantial growth}

This section provides illustrations that give a sense of the scale that PB has reached over the last three decades, with the caveat that seasoned PB specialists agree there is continued difficulty in computing accurate numbers of PBs experiences/activities taking place. For instance in Brazil it has been noted that "the 423 cases raised by the last RBOP" survey (2015) probably include some experiences that can loosely be called PB, since the study did not adopt a single model... [which means] it is still not possible to provide conclusive answers about the number of PB [experiences] in Brazil”" (Fedozzi et al. 2018, p. 118). The important aspect here is that, despite experts' commentary on democratic fatigue in Brazil (García Espín and Jiménez-Sánchez 2014; Accioly Jr et al. 2002), the reality on the ground indicates that PB still captures local government and civil society's imagination and the number of PB interventions in Brazil has never been so high even if the 2015 RBOP survey numbers may be slightly overestimated. Similarly, a recent essay on African PB suggests high numbers of PB initiatives: "To date estimates indicate more than 500 cases" (Kanouté and Som-1 2018, p. 78); notably, in Cameroon the most recent data shows a significant 107 PB experiments, "but the reality could be much beyond". ${ }^{6}$

Accurate counting of PB experiences with under and over-estimations remains a challenge well beyond Africa and Latin America. However, their large number cannot be denied. In the Philippines, the grassroots PB programme, formerly called Bottom-up Budgeting, by 2015 had expanded to virtually all local government units (1,633 in total). However, the number of projects actually implemented is notably low, so closer examination would be needed to evaluate if PB has been effective. Conversely, some experiences are significantly under-estimated: for example Chengdu, the capital of Sichuan Province in China with an estimated population of 20+ million, has been practising PB since 2008 and has funded over 100,000 PB projects - but is usually counted as a single experience. The reality is some 4,000 independent PB experiences in about 2,600 peri-urban villages and 1,400 urban sub-districts.

\footnotetext{
${ }^{5}$ RBOP: Rede Brasileira de Orçamentos Participativos / Participatory Budgeting Brasilian Network.

${ }^{6}$ Communication with the NGO ASSOAL, and RNHC, the Network of inhabitants from Cameroon (March 2019) that supports 27 NGOs: "107 PBs might be quite a conservative figure, as various institutions such as UN Women, $S N V$, The Delegation of the European Union, GIZ, etc have either launched or supported financially PB at local government (communes) level."
} 


\section{PB in Commonwealth countries}

The use of PB in Commonwealth countries has a long and complex history, too extensive to document here. However, through a review process of available literature, reports, videos, and unpublished communications from international $\mathrm{PB}$ events over the last three decades, this paper limits itself to identifying some trends and highlighting issues to be explored further in relation to the links between PBs and SDGs. Overall, references to PB in multiple forms exist in at least 21 of the 53 Commonwealth countries. $^{7}$ The 31 small states, of less than 1.5 million inhabitants, and especially the 25 small islands nations, are the least represented. The identified PB experiences can be mapped on to the four phases outlined above. Most countries are within the second and third phases of expansion beyond Brazil and of diversification, although some are in the fourth phase of consolidation that has been taking place over the last decade.

A closer look first at Commonwealth Africa illustrates the importance of PB on the continent. As part of an African PB inventory (Cabannes 2012), covering the period since the first emergence of PB in 2003 up to 2011, 48 out of the 162 African experiences identified took place in ten Commonwealth countries: Cameroon (17), Mozambique (6), Uganda (5), Zimbabwe (5), ${ }^{8}$ South Africa (5), Malawi (3), Tanzania (3), Kenya (2), Zambia (1) and Namibia (1). Further research would be needed to fully document these early experiments. More recently, there has been some documented PB experimentation in Sierra Leone, Rwanda and Nigeria and this is outlined below.

There has also been substantial experience in PB in other Commonwealth regions, including Asia (India, Sri Lanka and Malaysia), and Commonwealth OECD countries (Australia, Canada, New Zealand and the UK). With the exception of some recorded preliminary advocacy on PB in Jamaica and Papua New Guinea, the Commonwealth island nations in the Pacific, Caribbean and elsewhere have to date had least exposure to PB activities.

\footnotetext{
${ }^{7}$ In 2019, the 53 countries of the Commonwealth by region were: Europe: Cyprus, Malta, United Kingdom; Americas: Antigua and Barbuda, The Bahamas, Barbados, Belize, Canada, Dominica, Grenada, Guyana, Jamaica, Saint Lucia, Saint Kitts and Nevis, Saint Vincent and the Grenadines, Trinidad and Tobago;

Africa: Botswana, Cameroon, eSwatini (Swaziland); The Gambia, Ghana, Kenya, Lesotho, Malawi, Mauritius, Mozambique, Namibia, Nigeria, Rwanda, Seychelles, Sierra Leone, South Africa, Uganda, Tanzania, Zambia; Asia: Bangladesh, Brunei Darussalam, India, Malaysia, Pakistan, Singapore and Sri Lanka; Pacific: Australia, Fiji, Kiribati, Nauru, New Zealand, Papua New Guinea, Samoa, Solomon Islands, Tonga, Tuvalu and Vanuatu (The Commonwealth 2019 http://thecommonwealth.org/member-countries).

${ }^{8}$ Whilst Zimbabwe left the Commonwealth in 2003, as far as PB is concerned various Zimbabwean champions are still involved in PB within the region, such as the Municipal Development Partnership for Eastern and Southern Africa, and have maintained constructive links with fellow African Commonwealth organisations.
} 


\section{Conceptual PB perspectives and underpinning influences within the Commonwealth}

At least four different rationales for the adoption of PB can be identified in the various examples:

Influence of Porto Alegre and Brazilian PB work on early adopters in the Commonwealth. This legacy can be felt in the first such experiment, in Montreal's Plateau Mont-Royal borough, and is still evident in PBs taking place in Quebec Province, both in Canada. (Rabouin 2009). ${ }^{9}$ The first wave of PB actions in the UK, from 2000 to 2007, was also inspired by Porto Alegre, as mentioned by Jez Hall (2018), who was influential in the introduction of PB in the UK. His advisory role for the consolidation of PB in Scotland suggests that the Porto Alegre spirit and tools, somehow, can still be felt. Cameroon stands as the third example of the Porto Alegre legacy in the Commonwealth, as the early experiences launched in 2003 resulted partially from the exchange of knowledge and know-how with Brazilian and Uruguayan colleagues, and further exchanges were developed over time. Beyond these three cases, the iconic Porto Alegre case has frequently been cited in other Commonwealth countries' research and experiments.

New Public Management (NPM). This refers to an approach to running public service organisations and state institutions that borrows from the private sector with a tangential aim of participatory modernisation (Barzelay 2001). The introduction of business principles is made on the assumption that these are more efficient. Significantly, the participatory modernisation components of NPM and the experience of Christchurch, New Zealand have influenced the German experience of PB (Sintomer et al. 2005) more strongly than have Porto Alegre and other Latin American experiences.

Good governance. A third major source of influence relates to 'good governance' theories, which focus on PB as a tool for social accountability, transparency and reducing corruption. From this perspective "participatory budgeting and planning $(P B P)$ is an internationally recognised governance and social accountability tool" (Verité Research 2017 p.3). This focus, largely driven by international agencies and organisations - and, for example, firmly entrenched in the Sri Lankan experience highlighted in this paper - helps to explain why so many similarities can be found in very distant PB experiences.

Kerala People's Campaign: This campaign, launched in India in 1996, remains a key reference internationally (Isaac and Franke 2002). Although not specifically classified as PB, it provides a powerful demonstration of how local PB processes contribute to the attainment of SDGs, and the advancement of rural villagers, women and young people. The Kerala campaign's influence in India and beyond remains limited so far, even if highly praised in Brazil, Latin America or Spain (Berbel and Villansante 2011).

\footnotetext{
${ }^{9}$ Rabouin's 2009 book clearly establishes this legacy and reference.
} 


\section{The 21 Commonwealth countries with known PB experience can be organised into three categories:}

a) Significant Commonwealth PB experience

Five out of the 53 countries have implemented a significant number of PB initiatives, from consultative low-profile experiments to profound changes in local governance models and power relations. As these are relatively well known and documented, they will be referred to here only briefly - but they deserve great attention as beacons of PB innovation and achievement within the Commonwealth. Since 2003 when PB was launched in four municipalities in Cameroon, in the aftermath of the 2003 Africities Summit, the practice has seen swift growth (Africa Research Institute 2014) across the country, reaching an impressive 107 experiences by 2019. This expansion has been driven by three factors: the decentralisation process (Law 18/1/1996); the role played by civil society, notably RNHC, the Cameroon Network of Inhabitants; and the advocacy and training role played by ASSOAL, a national NGO (Cabannes 2017). In Canada, the first PB experiments took place in the early 2000s in the Plateau Mont-Royal district of Montreal (Cauchy 2006), within Toronto Community Housing, and in the city of Guelph (Lerner and van Wagner 2006). Since then, and despite significant volatility and interruption (Goldfrank and Landes 2018), PBs in Canada have constantly expanded and stretch today from the east coast (eg Hamilton) to the west coast (eg Victoria), under multiple and often extremely innovative forms. Two examples are Shape your budget, a tool for modelling of the entire municipal budget in Halifax, Nova Scotia, and Montreal's 2012 Programme Triennal d'Immobilisation (L'apathie c'est plate 2012) which provides tools for analysis of the city's capital budgets and running costs over three years.

Although PB has been used in the UK since the early 2000s (Hall 2018), and there is welcome recent activity in Northern Ireland ${ }^{10}$ and Wales, ${ }^{11}$ it is Scotland which can be considered the engine for PB in the UK (Escobar et al. 2018). There has been swift expansion since 2010, including an impressive scaling-up from 2014 to 2018 (Hall 2018), with all local authorities committed to PB, resulting partially from the agreement between the Scottish Government and the Convention of Scottish Local Authorities (COSLA). ${ }^{12}$ Out of these five countries, it is Scotland's policy drivers for PB which are most in tune with the achievement of the SDGs, and therefore of particular interest to this paper. In Mozambique, after legislation on decentralisation was passed in 1997, the town of Dondo paved the way in 1998 for a steady stream of PB experiences, albeit at a much lower level than in Cameroon (Figueira 2010). International organisations ${ }^{13}$ have played a major role in this, along with the National Association of Municipalities of Mozambique (ANAMM). The planning and budgeting governance model invented by local actors in Dondo, remains one of the most innovative in Africa (Cabannes and Delgado 2014).

\footnotetext{
${ }^{10}$ Participatory budgeting in Northern Ireland www.participatorybudgetingworks.org/about

${ }^{11}$ Participatory budgeting in Wales https://pbnetwork.org.uk/category/geographic/wales/

12 Participatory budgeting in Scotland http://whatworksscotland.ac.uk/publications/hope-for-democracyparticipatory-budgeting-in-scotland.

${ }^{13}$ Austrian Aid in Dondo, UN-Habitat in the first wave of expansion, and recently the World Bank in Maputo.
} 
In Australia, PBs are important more for their unusual characteristics than their number: they "constitute a significantly different branch from the tree of participatory budgeting initiatives worldwide" (Hartz-Karp and Weymouth 2018). Unlike most PBs, which debate on a percentage of the investment budget, here the citizens, randomly selected into 'People's Panels' scrutinise and give an opinion (without, however, decision-making power) on the total municipal budget. In other experiments, as in metropolitan Sydney's City of Canada Bay Council, the local authority engaged not only citizens but "council staff - as well - through a parallel process convened by the Council, using a randomly selected staff panel" (Thompson 2012).

\section{b) Isolated $P B$ projects or experiences}

This second category refers to one-off experiences or those limited to a specific region or city. Most, but not all, are donor-driven and only last the duration of the project, with limited sustainability, if any. They often, however, introduce quite innovative practices worthy of attention, documentation, dissemination and upscaling. They pave the way to meet the SDGs at local level. Identifying and documenting these isolated cases is challenging as it is necessary to piece them together from reports, grey literature and films, pictures and testimonies, relying on a network of informal informants from the international and local PB communities. The list of examples cited here needs to be expanded in the future.

Looking first across Commonwealth Africa, in Rwanda, the European Union and the NGO Action Aid jointly funded a three-year project called 'Strengthening Civil Society Organisational Capacity in Promoting Sustainable Agriculture Policies and Citizens' Participatory Budgeting-SCAB' (20142018). Active in eight rural districts, one of its most innovative aspects was its successful debating and lobbying to increase the proportion of the national agricultural budget going to smallholder farmers who are primarily women (Mbonyinshuti 2018). The 'My school, my vote' ${ }^{14}$ project in Zambia in 2016 neatly illustrates both the limits and the potential of a one-year donor-driven and donor-controlled (in this case by USAID) PB project, which took place in Mukuna and Nkana secondary schools in the Zambian copper belt. Despite the meagre resources debated by the project, it was nevertheless a pioneer of school PB in Africa, using a methodology and digital tools fully in line with practice in other continents. Unfortunately, it is not known whether this has been renewed or expanded. In south-west Nigeria, the Ekiti State PB experiment, funded by the Ford Foundation and implemented by Community Life Project (CLP), aimed to improve rural life through PB. In 2012, following a massive capacity-building programme by CLP, relations between state officials and the people became more transparent, and 177 local construction projects were implemented under people's control in 170 communities. Local people were able to choose their contractors and buy the building materials directly - quite an innovation in terms of transparency and accountability in the Nigerian context.

\footnotetext{
${ }^{14}$ School PB in Zambia, video broadcast on 6 July 2017.
} 
Further isolated PB experiences, mostly taking place without any budgetary or institutional support, have been reported in countries such as Tanzania, Kenya, Zimbabwe (Chirenje et al. 2013), Uganda and South Africa (Leduka 2009), primarily during the early years of PB in Africa. These experiences are characterised by a 'flexible' vision of PB (MDP and UNHSP 2008) and definitional difficulties, as discussed by Sintomer et al. (2013 p.60), partly because "the inherited administrative colonial structure bequeathed a local government system in which elected officials have more limited political power compared to mayors elsewhere, and in which a higher level of discretional control over local budgets is provided to technical city managers, as well as central/ministerial institutions". ${ }^{15}$ Such a situation might explain why in some countries such as Uganda and notably South Africa the enabling budgetary and institutional environment has not been conducive to PB - despite the fact that, in South Africa, there is a suitable legal framework fully in place. ${ }^{16}$ Since the constitution of 1996 , considering the White paper on Local Governments or the Municipal Structure Act (1998), or the 2003 Municipal Finance Management Act that supports participation in municipal budget processes.

Looking next at Commonwealth Asia experience, participatory budgeting and planning (PBP) was introduced in Sri Lanka in the early 2010s, with Asian Foundation technical support and covered eight of the country's 23 municipal councils. One of the first tasks of the Foundation was the creation and dissemination of a facilitator's guide (Asia Foundation 2011), which was extremely structured and introduced a top-down perspective to PB. The most successful municipality so far in this series of PB experiments is Badulla, a city of c.50,000 inhabitants where, in 2013, people's priorities, identified through public consultations, were able to direct over $50 \%$ of capital expenditure, representing about US\$210,000 (Verité Research 2017). Some regional or isolated cases have arisen without the help of external resources: one example is Pune in India, which has "experimented [with] a form of Participatory Budgeting since 2006, when it was first introduced formally by the Pune Municipal Corporation (PMC). Citizens' organizations have played an important role in initiating and shaping it" (Sanskriti and Madhale 2013 p. 1). A 2013 assessment of this experience reveals, once again, that despite limitations and need for improvement $\mathrm{PB}$ can deliver significant achievements, such as "the simplicity of the process for citizens, taking place regularly every year, [with the result that] a substantial quantum of funds has been allocated and there is some response to suggestions from the poor" (Sanskriti and Madhale 2013, p. 41). Despite these positive outcomes, however, PB experiments have remained limited in India and have not cross-fertilised or been replicated beyond municipal boundaries. The Kerala People's Plan outlined above is a case in point. Similarly, to date the unique and innovative PB experience in Malaysia cited below remains limited to Penang State, although it could potentially expand nationally as it has been upscaled to a regional policy in 2019.

\footnotetext{
${ }^{15}$ For further discussion see in UCLG 2008 and UCLG 2010.

${ }^{16}$ For a comprehensive description of the legal enabling framework see Leduka (2009).
} 
c) $P B$ remains at advocacy, not implementation, stage

A third category includes countries in which PB is debated and advocated for, sometimes in parallel with limited initiatives (eg Sri Lanka, India), or as a way of breaking new democratic ground. This advocacy is spearheaded by a range of actors from scholars in Papua New Guinea (Chohan 2016) and Bangladesh (Hossain et al 2014), to NGOs and foundations in Sri Lanka, Sierra Leone, and from bloggers to local and national media in Jamaica, New Zealand, Malawi. ${ }^{17}$ However, these initiatives are not always followed by identifiable actions, or their results are difficult to identify. ${ }^{18}$ Proper follow-up and collaborative research would be beneficial, as these advocacy efforts might yield valuable insights and lead to future PB developments in the country or city where they took place.

\section{Critical perspectives on the current status of PB within the Commonwealth}

PB experiments, and more generally citizens' participation in budgetary affairs in local governance, have over the last 15 years been critically scrutinised by scholars, media channels and civil society organisations. PB has shone a light on fundamental structural limitations in some countries' legal frameworks, as well as administrative, political or elite 'capture' of governance mechanisms, which can render PB ineffective. Situations of this kind in South Africa and Nigeria deserve more discussion within thr Commonwealth, both from a democratic perspective and in order to identify the most crucial challenges to $\mathrm{PB}$ - and how to address them. In South Africa Fuo (2016, p. 1) argues that the "legal framework for participatory budgeting creates an illusory right for citizens to participate in municipal budgeting processes". Taking one example, Leduka (2009) assessed participation in budgeting in Mantsopa Local Municipality in Free State Province, South Africa and concluded that: "The political and administrative elites are still holding on to power that should be in the hands of citizens. Civil society groups are still being neglected in local government decision-making. Citizens are also not being encouraged and mobilised to take part in the budget process. The issue of racial discrimination in engaging citizens in decision-making still exists" (p.iii). Similarly, Iloh and Nwokedi (2016) underline that "budgeting in Nigeria is seen as an exclusive preserve of the executive arm of government" and argue that "participatory budgeting might be difficult in Nigeria due to the vested interest of the ruling class". Interestingly though, they use examples from Latin America to show that "participatory budgeting is the remedy to the myriads of problems being encountered in budgeting in Nigeria" (p. 13). Sobanjo (2016) focuses on Ijede LCDA in Lagos State, and the evidence gathered "revealed the fragility of $P B$, when local government officials suspended the process because other financial demands were considered more expedient than $P B, a$ situation made possible in the absence of a legal framework institutionalizing the process" (p. 199).

\footnotetext{
${ }^{17}$ This includes the Centre for Policy Alternatives, Sri Lanka (Fowler et al. 2013); Citizens Budget Watch, Sierra Leone; international projects (i.e. Open Budgeting Project, Jamaica, spearheaded by the Caribbean Open Institute (2016); some bloggers (i.e The Good Society blog, New Zealand (Rashbrooke 2016) as well as local \& national on line and printed newspapers (i.e. Awoko Newspaper (2016) in Sierra Leone highlighting the Africa Health Budget Network or The Nation (2012) in Malawi, summarising the benefits brought by PB).

${ }^{18}$ Some are difficult to identify i.e. Janaagraha 2017 announcing an upcoming PB launching in Delhi, India, in 2017 or $C O I$ website announcing that a pilot PB will be implemented in August Town, Kingston, Jamaica as part of their 2015/2016 programme.
} 


\section{Participatory budgeting and its links with SDGs}

While this paper primarily examines PB links with SDG Target 16.7 ("Ensure responsive, inclusive, participatory and representative decision-making at all levels") $\mathrm{PB}$ contributions also have a bearing on SDG 5 ("Achieve gender equality and empower all women and girls"), SDG 10 ("To reduce inequality within and among countries") and SDG 11 ("Make cities inclusive, safe, resilient and sustainable"). That said, systematic evidence-based research to document the multiple direct and indirect contributions - similar to that undertaken in relation to the Millennium Development Goals remains to be done (Cabannes 2004b).

\section{PB contribution to attaining Target 16.7}

Responsiveness. PB typically funds projects that respond to citizens' priorities, using local public resources. Priorities are established either through a pre-established list of eligible projects, defined by the local government, that participants will choose from, or more commonly from a list of project ideas resulting from a people's assembly that, once developed into viable projects, will be prioritised through a citizens' vote. The projects are then normally implemented the following financial year. Inclusiveness. Most PB initiatives increase participation of either organised or non-organised civil society (both models exist) and have a demonstrated capacity to reach hard-to-reach social groups that have historically been overlooked by local government - although of course much more remains to be done in this direction. Some prominent PB initiatives with a specific social focus - for example on older people, women, young people, ethnic minorities, refugees, migrants, and/or the LGBT+ community show that $\mathrm{PB}$, under certain conditions, contributes powerfully to the inclusive dimension of SDG Target 16.7. Some of them will be introduced later in this paper. Participatory process. Even if only a small percentage of the population participates (and participation levels vary widely), PB by its essence generates a deep - and highly variable - level of participation and deliberative intensity. It is important here to recognise that there are two cycles within a PB project, and civil society participation is essential to both. In the first cycle of $\mathrm{PB}$, a political decision is made to assign a certain amount of public resources which are up for debate, and specific projects are chosen for funding and defined. The second cycle of PB covers the period in which resources are made available and the project is actually implemented. Civil society participation is crucial during this second cycle for optimising public resources, reducing costs, and eliminating corruption. Both cycles encourage the modernisation of local government administration and tend to generate more effective institutions, even if the amount of public resources in question is limited. In addition, active participation during this second PB cycle appears to be essential to reinforce trust among social groups which have a limited tradition of participating, or a reluctance to do so. 
Representative decision-making. Not all PBs are equal. In some cases the process is consultative, and citizens are invited, either online and/or in face-to-face meetings, to give an opinion and make suggestions. In others it is binding, and citizens' votes are final in deciding on projects. Binding PBs are much more powerful for building trust and long-term engagement, and also tend to be more sustainable and durable (Dias 2018). The mechanisms by which citizens continue their involvement in the 'second cycle' mentioned above (the implementation phase) are also an important element to consider in order to link PB with SDG Target 16.7. These can range from a specific people's commission to elected delegates, voluntary groups, or mixed public/community groups (Cabannes 2004a). A third element to consider in relation to representative decision-making is whether participants may be drawn only from representative or registered civil society organisations (as in Peru, for instance) or whether participation is universal for all adult citizens (the Brazilian model) - or a mixture of both. It is also worth noting that some PB initiatives, in order to improve the representativeness of decision-making, choose to elect, during the deliberative assemblies, delegates who will play an active role through both cycles.

\section{PB links with SDGs 5, 10 and 11}

Experiences from Penang in Malaysia, Chengdu in China, Surakarta in Indonesia, Yaoundé in Cameroon and Rosario in Argentina clearly demonstrate that PB can significantly contribute both to SDG 5 'Gender equality' and SDG 10 'Reduce inequality'. ${ }^{19}$ In Penang, PB was found to promote social equality by functioning as 'a tool to empower the community and challenge the status quo by putting people in the centre of budget planning'; while in Chengdu it contributed to spatial equality, as it was 'initiated with the aim of reducing the urban-rural public services gap' (Cabannes 2018). Using PB to provide basic services (and thus contribute to SDG Target 11.3) is the number one priority of citizens in most cities, particularly in low-income settlements (Cabannes 2014). Opening up roads and alleys or paving streets, are usually the most common, along with wastewater management and treatment, energy and public lighting, and stormwater drainage. Other basic services such as transport and mobility, drinking water supply and solid waste management are also popular initiatives for PB funding. One study spanning 20 cities examined over 20,000 PB-funded projects worth over US\$2 bn in three years, and found that in all cases PB had contributed to improving basic services, including how they are delivered and to whom. The same study found that PB projects are cheaper and better maintained than non-PB projects, thanks to the community control and implementation oversight that constitutes the second cycle of $\mathrm{PB}$ (Cabannes 2014). In this way, PB contributes to sustainable human settlement planning and management (Target 11.3).

\footnotetext{
19 The international workshops and networking sessions on PB, as part of the World Urban Forum in Kuala Lumpur, Malaysia in February 2018, explored to what extent PBs practised in Asian and Russian cities could contribute to attaining some of the SDGs. Interestingly the various panellists addressed the question: 'Which of the SDGs do you think PB contributes to more and why? See Cabannes (2018).
} 


\section{Local government initiatives to ensure PB is successful}

\section{'At all levels': PB takes place effectively in councils of all sizes and at different scales}

One of the major challenges stressed by SDG 16, particularly through target 16.7, is inclusivity: that the peaceful societies, and just institutions it envisions should be achieved at all levels. PB uniquely achieves this, as it can operate from the most micro 'street' level right up to regional and national levels. It happens in territories of all kinds and all sizes, from villages with a few thousand inhabitants in Kerala, to small urban centres such as Edzendouan in Cameroon, to intermediary cities like Dondo in Mozambique or Badulla, Uva Province, Sri Lanka, and municipalities located at the periphery of metropolitan regions such as Boisbriand, located in the suburbs of Montreal, Canada, and to regional capitals such as Halifax, Canada, major Metropolis such as Chengdu, China and São Paulo, Brazil and national capitals such as Yaoundé, Cameroon. There are examples of PB experiences above the local government level including at the subnational regional level such as in Scotland (Escobar et al. 2018), Penang State, Malaysia, or Ekiti State in Nigeria, as well as recent national level PB experiments in South Korea and Portugal.

In a growing number of countries PB develops at sub-municipal levels. Notable examples are the USA (ward level in Chicago and New York City), Cameroon (commune d'arrondissement level in Yaoundé), Russia (ward level in St Petersburg), Malaysia (sub-municipal level in Penang), and Portugal (parish/ juntas de freguesias level). $\mathrm{PB}$ at this level tends to be more inclusive and responsive to diverse social groups, and to enhance citizens' participatory decision-making and are therefore particularly relevant for attaining SDG 16.7. One limiting factor, however, is that this tier of government typically controls only limited public resources. A parallel trend, working in the other direction, is the growing number of PB initiatives spearheaded and/or implemented by regional governments (state, provincial or regional). Documented examples include an upscaling of PB from a lower tier of government (Malaysia), a topdown decision from a higher-level ministry supports regional governments (Krai) of the federation in their efforts to implement PB at district, village and city levels, (Ministry of Finance, Russia), and political decisions taken at regional level (Jalisco State, Mexico and Los Rios Province, Chile).

Such experiences tend to bring both participatory decision-making and representative decision-making to very small villages and rural districts that would not be included otherwise. Russia's Local Initiatives Support Programme (Shulga et al 2017) and Mexico's Vamos Juntos ('Let's go together') initiative in Jalisco State (Hernandez 2017) are good examples, channelling limited public resources to the poorest regions and most vulnerable people, notably rural inhabitants and first nations. In the Vamos Juntos PB experience in Jalisco State in Mexico the focus in the first year was on the poorest five sub-regions and then next five in year two, etc (Hernandez 2017). In focusing first on the poorest regions, the PB process was more responsive to rural inhabitants and historically excluded first nations and developed aremarkable inclusive capacity, in line with SDG 16.7. A notable feature of Vamos Juntos was its small-scale but enthusiastic and agile young team, able to move nimbly from one municipality to another, accumulating knowledge and skills and enabling more effective local government (CIESAS 2018). 


\section{PB as a powerful tool to support the SDG principle of 'leaving no one behind'}

A large number of innovative PB experiments have been carried out by local governments to include and benefit traditionally excluded and disadvantaged social groups: for example homeless (i.e. Paris, São Paulo), LGBT+ (various Brazilian experiences), migrant workers (i.e. Taoyuan, Taiwan, see below), youth (multiple experiences, see Valongo, Portugal below), women (i.e. Solo/Surakarta, Indonesia, Seville, Spain), ethnic minorities in cities (i.e. São Paulo, Brazil or Rosario, Argentina), extreme poor (i.e. Yaoundé, Cameroon), disabled (i.e. Sanxia district, Taiwan; La Serena, Chile), rural districts of regional or national cities (i.e. Quito or Cuenca, Ecuador; Chengdu, China) (Cabannes 2019).

\section{PB for migrant workers: learning from Taoyuan, Taiwan}

A limited number of cities that have been giving a specific PB focus to the inclusion of migrants, refugees, or ethnic minorities (Seville, New York, Penang, to name a few). The PB initiative of the city of Taoyuan (2.3m inhabitants) in Taiwan is particularly innovative in having earmarked resources (about US\$1m in 2017) for migrant workers from Vietnam, Thailand, Indonesia and the Philippines, who have been characterised as "marginalized politically and suffering from cultural discrimination". 20 The projects funded, chosen after a PB process, had to fall within a broad concept of leisure which valued migrants' culture, art, and sports. All projects were soft projects, meaning they did not provide physical equipment or amenities. At each stage of the PB process, from programming to implementation of selected proposals, migrant participants were directly involved. This demonstrates that PB with excluded groups, as opposed to for them, is feasible. In a short timeframe, it yielded extremely positive tangible and intangible effects, such as changes in attitude and perception among the Taiwanese population and Taoyuan civil servants; better understanding between migrants, the municipality, and Taiwanese nationals; recognition of the value of different cultures; and a reduction in discrimination. ${ }^{21}$

\section{Increasing the inclusion and decision-making power of young people}

Participatory budgeting involving young people began in 1997 in Barra Mansa, Brazil, and has been multiplying ever since, primarily across Latin America, Europe and North America, and today is implemented in hundreds of primary schools, secondary schools, colleges and even universities. Many cities have lowered the minimum age for PB participation in order to include younger cohorts to engage, participate and vote in city-based PBs. Such measures are a prime contribution to meeting SDG Target 16.7 over the long term: they distribute power to younger generations, both disadvantaged and nondisadvantaged, they constitute a powerful civic school for deliberation and participation, and the evidence strongly suggests, foster future participation in civil society. Youth PB initiatives are thus fully in line with the four indicators contained in the policy brief drawn up by the respected V-Dem Institute for measuring SDG Target 16.7(V-Dem Institute 2017). The experience below illustrates such contribution.

\footnotetext{
20 Case study on Taoyuan by Kai Ling Luo, Research Fellow, European Research Centre on Contemporary Taiwan, Germany and Shizhe Lai, Senior Executive Officer, Taoyuan, Taiwan (2018). This documentation was carried out in the context of the study for the World Bank on the Role of $P B$ in addressing the needs of disadvantaged groups. (See Cabannes 2019.)

${ }^{21}$ Case study on Taoyuan (Cabannes 2019).
} 


\section{Youth Participatory Budgeting}

Over the past six years, Valongo Municipality ( 100,000 population) located at the periphery of Porto Metropolitan Region (1.8 million) in Portugal has made huge efforts to include young people through Youth Participatory Budgeting in all public schools, with strong emphasis on those located in rural districts, and least serviced. Additional efforts since 2018 were made to benefit the elderly through an innovative inter-generational PB project associating elderly and youth. A parallel initiative, quite unique and innovative was launched in 2018, and repeated in 2019 in another PB stream, "I matter" for civil servants working in the municipality, through which they select initiatives that will improve their working conditions. This directly impacted target 16.7. "build effective, accountable and inclusive institutions", with a limited amount of resources. Another aspect of the initiative is that the majority of the PB team, including its senior officer, are women, and this is clearly a woman's led process, quite noticeable in the Portuguese context, which contributes to achieving indicator 16.7.2. As a result, since 2014 around 270 ideas were proposed, more than 100 became eligible for voting and over 12,000 young people (6 to 35 years) voted. In relation to the project I matter, 70\% of Valongo's civil servants (570) participated and voted in the "Imatter" PB process, and the most voted projects were those proposed by women. The four complementary indicators (V-Dem Institute 2017) for 16.7 have been positively attained: deliberative component; participatory component; civil society; power distribution and reversion. So far, these initiatives have worked well. However, the limited resources put into PB debate might have an adverse effect in the process, if the level of requests continues to grow and expand to different social groups. The answer from the local government has been very wise: when project demands were similar in more than two schools, or over the years, the requests from projects were included in the normal budget and reproduced in all schools (for example, the ongoing work and development of high-technology classrooms in every public school, as well as the implementation of outdoor sports equipment).

\section{'Leaving no place behind': PB's contribution to spatial and social justice}

In order to leave not only no one but no place behind, various local and regional governments are channelling city PB resources to their more disadvantaged districts (e.g. Rosario, Argentina), and neighbourhoods (Seville, Spain), or smaller areas, in an attempt to increase spatial as well as social justice (e.g. Belo Horizonte, Brazil, within its regional PB modality), in a perspective of social justice and spatial justice. These initiatives are thus different from conventional city-based or district-based PB, where money is evenly allocated throughout the territory, and instead focus on predefined deprived areas, such as low-income housing estates, rental compounds (e.g. in Paris or Penang for instance) or rural districts within municipal boundaries (e.g. Chengdu, China or Cuenca, Ecuador), or villages which are remote and/or poor (eg Arzgir District villages in Stavropol Region, Russia). In these cases, specific resources are predefined through different techniques. Such PB for specific disadvantaged areas may be standalone PB (Chengdu and Cuenca during the first years) or be part of combined PB (Paris, Cuenca recently). 


\section{Cumulative impact of PB on policies and programmes to achieve SDG Target 16.7}

As explored elsewhere (Cabannes 2019) PB practices have had multiple impacts on existing civic programmes and policies. Some of these are: a) mainstreaming of PB projects into municipal programmes and policies; b) $\mathrm{PB}$ as a driver of municipal and institutional change, for example in focusing greater attention on disadvantaged groups; c) PB as an engine to shift from isolated participatory experiments to a system of participation which benefits the excluded; d) PB as a catalyst of reform to regional laws and institutional mechanisms; e) impact on country-level PB policies. Despite these powerful examples, however, the capacity of PB to generate meaningful changes in wider policies and programmes remains very little documented. This should be remedied, as PB clearly can play a central role in speeding up the achievement of SDG Target 16.7, and also SDG Target 11.3 on inclusive and sustainable urbanisation. Two relevant examples will be briefly described here.

$P B$ as an engine to transform isolated participatory practices into an institutionalised system

In March 2016 the Metropolitan District of Quito (MDQ), pressed by local civil society groups (neighbourhood associations, women's movement, indigenous movements), enacted and implemented an ordinance (OM 102) institutionalising PB practices benefiting vulnerable groups across its 32 urban districts and 33 rural districts, and integrates various forms of socio-organisation. The project was especially innovative with a continuous improvement of processes involved in the component mechanisms. The following PB practices were entrenched: a) recognition and support of ancestral forms or organisations and collective land ownership for first nations; b) citizen oversight and control of public sector activity; c) citizen participation in debates and the design of PB; d) establishment of a unique 'metropolitan system of citizen participation and social control' with 11 interconnected mechanisms; and e) increased protection for, and devolution of power to, rural parishes (which are typically the most deprived) to, include 'cabildos abiertos', a system of public hearings and open sessions introduced in colonial times.

$P B$ as a catalyst of reform to regional laws and institutions

PB experiences in Seville from 2004 onwards were the starting point for a long and winding process that eventually led to a regional law on citizen participation. Approved in 2017, the law mandates citizen participation in budgetary discussions, and promotes the role of women and young people. Unfortunately, the gains obtained in Seville through PB from 2004 to 2011 for other disadvantaged groups, such as migrants, refugees, and the LGBT+ community, which were included in the first version of the law drafted with direct involvement from PB staff, were dropped from the final version. On a more positive note, however, the law will "foster the promotion and dissemination of participatory budgeting processes" (Junta de Andalucía 2017, chapter 2). 


\section{Conclusion and recommendations}

In order to support participatory policies and implement PB processes as a way to achieve SDG 16 and its targets, evidence gathered so far ${ }^{22}$ strongly suggests the following measures, subject to appropriate tailoring to local circumstances:

a) more financial decentralisation and channelling of resources to local level;

b) more systemic linking of PB practices and 'bottom-up' proposals with local and regional planning;

c) more training of and learning within civil society - rather than just among civil servants, as is currently often the case - in order to increase people's autonomy and empowerment;

d) better good practice and innovation dissemination through international and national association of cities and local governments and PB municipal champions on PB as a powerful way to achieve SDGs. Such international and national campaigns would bring a much-needed awareness to many local authorities, and would help to upscale and expand PB good practices;

e) greater participation by disadvantaged and vulnerable groups in PB processes, and more PB resources channelled towards them, based on tried and tested methodologies;

f) measures to enable citizens, including disadvantaged groups, to participate in the definition of PB rules that are mostly defined by local governments. A bold approach of this type ${ }^{23}$ would represent a decisive devolution step, allowing the emergence of a fourth power - community power - alongside the existing legislative, executive and judiciary branches;

g) promotion of innovative forms of local governance, such as PB elected councils, or committees with significant representation of disadvantaged groups; and

h) inclusion of policy and administrative reform within the scope of PB projects, so that maximum positive impact can be achieved. The evidence base ${ }^{24}$ suggests that policy reform is the only way PB can upscale sufficiently to address social challenges sufficiently to contribute at scale to realising the SDGs.

As a final comment, the author suggests that - given PB's growing public profile, the many thousands of PB initiatives taking place each year, and their direct and positive impact on various SDGs - PB could be harnessed as a relevant indicator to monitor the SDGs, particularly Target 16.7.

\footnotetext{
${ }^{22}$ These lessons and recommendations are primarily based on field evidence examination and interviews with experts contained in Cabannes 2014 and 2017a.

${ }^{23}$ Self-determined rules - autoreglamento in the case of Seville or regimento interno in Brazil - are quite uncommon in the Commonwealth so far.

${ }^{24}$ See The role of Participatory Budgeting in addressing the needs of disadvantaged/vulnerable groups, section 2.8 , for the impact of PB on more socially oriented policies and programmes (Cabannes 2019, unpublished report for the World Bank).
} 


\section{Declaration of conflicting interest}

The author declared no potential conflicts of interest with respect to the research, authorship, and/or publication of this article.

\section{Funding}

An earlier version of the paper was commissioned by United Cities and Local Government (UCLG) and will appear in the Global Observatory on Local Democracy's forthcoming GOLD Policy Series (more information at http://www.gold.uclg.org).

\section{References}

Accioly Jr., C., Herzog, A., Sandino, E. and Andrade, V.H. (2002) Participatory budgeting in the municipality of Santo André, Brazil: The challenges in linking short-term action and long-term strategic planning. Rotterdam: HIS

Africa Research Institute. (2014) The booklovers, the mayors and the citizens: Participatory budgeting in Yaoundé, Cameroon. London: ARI.

Asia Foundation. (2011) Facilitator's guide on participatory budgeting for local authorities in Sri Lanka. Colombo: Asia Foundation.

Awoko Newspaper. (2016) Sierra Leone News: To increase access to budget info... AHBN launches \#ValueOurHealth. April 14, 2016. Available at: https://awoko.org/2016/04/14/sierra-leone-news-toincrease-access-to-budget-info-ahbn-launches-valueourhealth/ [Accessed 26 April 2019].

Barzelay, M. (2001) The new public management: Improving research and policy dialogue. Wildasky Forum Series. Oakland: University of California Press.

Berbel, R. and Villasante, T. (2011) Kerala. La democracia en marcha. Madrid: El Viejo Topo.

Cabannes, Y. (2003) Participatory budgeting and municipal finance. Base Document. Launch Seminar of URBAL Network No 9, Municipal Government of Porto Alegre.

Cabannes, Y. (2004a) Participatory budgeting: A significant contribution to participatory democracy. Environment \& Urbanization, 16 (1), 27-46. https://doi.org/10.1177/095624780401600104

Cabannes, Y. (2004b) Participatory budgeting: Conceptual framework and analysis of its contribution to urban governance and the Millennium Development Goals. Concept Paper, Working Paper, UMP-LAC, UNHABITAT, UNDP. Available at: http://discovery.ucl.ac.uk/10660

Cabannes, Y. (2012) Répertoire des budgets participatifs en Afrique. Unpublished report and digital database. Rabat: UCLG-A.

Cabannes, Y. (2014) Contribution of PB to provision and management of basic services. Municipal practices and evidence for the field. IIED Working Paper. London: IIED.

Cabannes, Y. (ed.) (2017) Another city is possible with participatory budgeting. Montreal: Black Rose.

Cabannes, Y. (2017) A noteworthy experience in Yaounde $6^{\text {th }}$ Commune, Cameroon: Democratising and improving living conditions. In: Cabannes, Y. (ed.) Another city is possible with participatory budgeting, (pp. 149-158). Montreal: Black Rose.

Cabannes, Y. (2018) Highlights on some Asian and Russian participatory budgeting pioneers. Barcelona: IOPD; Surakarta: Kota Kita and London: UCL/DPU. Available at: https://www.oidp.net/docs/repo/doc362.pdf

Cabannes, Y. (2019) The role of participatory budgeting in addressing the needs of disadvantaged groups. Moscow: The World Bank. Unpublished.

Cabannes, Y. and Delgado, C. (2014) Dondo, Mozambique: A unique example of PB as a driver of good governance. In: Cabannes, Y. (ed.) Another city is possible with participatory budgeting, (pp. 103-110). Montreal: Black Rose. 
Cabannes, Y. and Lipietz, B. (2018) Revisiting the democratic promise of participatory budgeting in light of competing political, good governance and technocratic logics. Environment and Urbanization, 30 (1), 1-18 https://doi.org/10.1177/0956247817746279

Caribbean Open Institute. (2016) Project - towards greater citizen engagement and transparency through open budgeting in Jamaica. Available at:

http://caribbeanopeninstitute.org/civicrm/profile/view?reset=1\&id=1237\&gid=14 [Accessed 15 April 2019].

Cauchy, C.A. (2006) Le Plateau sur les traces de Porto Alegre: Élus et citoyens improvisent un budget participative, Le Devoir 9 Juin 2006.

Chirenje, L.I., Giliba, R.A. and Musamba, E.B. (2013) Local communities' participation in decision-making processes through planning and budgeting in African countries. Chinese Journal of Population Resources and Environment, 11 (1), 10-16. https://doi.org/10.1080/10042857.2013.777198

Chohan, U.W. (2016) The case for a parliamentary budget office in Papua New Guinea. Discussion Paper Series: The Art and Science of Legislative Budget Offices. Canberra: University of New South Wales.

CIESAS. (2018) Evaluación de Resultados de la Estrategia Vamos Juntos. Centro de Investigaciones y Estudios Superiores en Antropología Social, Guadalajara: Evalúa Jalisco.

Commonwealth. (2019) Member countries. Available at: http://thecommonwealth.org/member-countries

Community Life Project. (2017) Improving life through participatory budgeting. The Ekiti success story. 10' video.

Dias, Nelson. (Organisation). (2018) Hope for democracy. 30 years of participatory budgeting worldwide. Faro: Oficina.

Escobar, O., Garven, F., Harkins, C., Glazik, K., Cameron, S., Stoddart, A. and O’Hagan, A. (2018) Participatory budgeting in Scotland. El presupuesto participativo en Escocia: la interacción de la reforma del servicio público, el empoderamiento de la comunidad y la justicia social. En J. Molina \& J. M. Mayor (Coor.) Presupuestos Participativos: Abriendo el gasto público a la ciudadanía. Valencia: Tirant Lo Blanch.

Fedozzi, L., Furtado, A. and Rangel, R. (2018) Participatory, budgeting in Brazil: Elements for a brief evaluation. In Dias, Nelson (Organisation). Hope for democracy. 30 years of participatory budgeting worldwide. Faro: Oficina.

Figueira, A. (2010) Planificação e orçamentação participativa em Dondo, exercicio da democracia participative. Working paper, unpublished.

Fowler, B., Wijesundara, S. and Gajanayake, M. (2013) The budget process in Sri Lanka: Local and national issue analysis and recommendations. Colombo: Centre for Policy Alternatives.

Fuo, O. (2016) Participatory budgeting in South African local government: A right or illusion. World Academy of Science, Engineering and Technology International Journal of Law and Political Sciences, 10 (8).

García Espín, P. and Jiménez-Sánchez, M. (2014) Beyond the participatory process: Consequences in the interaction between civil society and local authorities. Paper prepared for the ECPR General Conference 2014, 3-6 September, Glasgow. Panel: Effects of Non-Electoral Participation in Local Politics.

Goldfrank, B. and Landes, K. (2018) Participatory budgeting in Canada and the United States. In: Dias, N. Hope for democracy. 30 years of participatory budgeting worldwide, (pp. 161-173). Faro: Oficina.

GTF (2019) Towards the localization of the SDGs. Local and Regional Governments' Report to the High-Level Political Forum. Global Taskforce of Local and Regional Governments. Barcelona: UCLG. Available at: www.gold.uclg.org/sites/default/files/Localization2019_EN.pdf [Accessed 17 July 2019].

Hall, J. (2018) Scaling up: Development of participatory budgeting (PB) within Scotland from 2014 to 2018. Communication at International PB conference, Stockholm, unpublished.

Hartz-Karp, J. and Weymouth, R. (2018) Australian participatory budgeting. In Dias, N. (Organisation). Hope for democracy. 30 years of participatory budgeting worldwide, (pp. 403-422). Faro: Oficina.

Hernandez, C. (ed.) (2017) Vamos Juntos. Hacia una Sociedad más participativa y corresponsable. Gobierno de Jalisco

Hossain, Z.A.N.M., Begum, A., Alam, M. and Islam, M. (2014) Participatory budgeting in Bangladesh local government context. Public Administration Research, 3, 28-43. https://doi.org/10.5539/par.v3n2p28

Isaac, T. and Franke, R. (2002) Local democracy and development: People's campaign for decentralised planning in Kerala, New Delhi. Lanham, Maryland: Rowman \& Littlefield. 
Iloh, E.C. and Nwokedi, M.E. (2016) Budget processes and participatory budgeting in Nigeria: Lessons from Latin America. ANSU Journal of Arts and Social Sciences, 5 (1), 135-154.

Janaagraha. (2017) Delhi government lays the foundation for participatory budgeting. Available at: www.janaagraha/delhi-government-lays-the-foundation-for-participatory-budgeting [Accessed 19 Feb 2017].

Junta de Andalucía (2017) Ley 7/2017, de 27 de diciembre, de Participación Ciudadana de Andalucía. Available at: www.juntadeandalucia.es/boja/2018/4/1 [Accessed 12 July 2019].

Kanouté, B. and Som-1, J.D. (2018) Participatory budgeting in Africa: A kaleidoscope tool for good governance and local democracy. In: Dias, Nelson (Organisation) Hope for democracy. 30 years of participatory budgeting worldwide, (pp. 77-87). Faro: Oficina.

L'apathie c'est plate. (2012) Décoder: le budget montréalais d'immobilisation et d'infrastructure. Available at: http://apathyisboring.org/media/jpegs/MTL_BUDGET_INFO_FR.html [Accessed 30 April 2019].

Leduka, M. (2009) Participatory budgeting in the South African local government context: The case of the Mantsopa local municipality, Free State province. Masters Thesis in Public Administration. Stellenbosch, South Africa: Stellenbosch University.

Lerner, J, and van Wagner, E. (2006) Participatory budgeting in Canada: Democratic innovations in strategic spaces. Amsterdam: The Transnational Institute.

Mbonyinshuti, J.A. (2018) SCAB Project. Promoting sustainable agricultural policies and enhancing citizens' participatory budgeting. The New Times, 28 March 2018. Available at: https://www.newtimes.co.rw/news/featured-scab-project-promoting-sustainable-agricultural-policiesand-enhancing-citizens [Accessed 30 April 2018].

MDP \& UNHSP. (2008) Participatory budgeting in Africa - a training companion with cases from eastern and southern Africa. Harare: MDP/UNHSP.

Rabouin, L. (2009) Démocratiser la ville. Le budget participative: de Porto Alegre à Montréal. Lux: Montréal.

Rashbrooke, M. (2016) The New Zealand initiative on local government and democracy. Good Society weekly round-up, posted November 22, 2016. Available at: http://www.goodsociety.nz/the-new-zealandinitiative-on-local-government-and-democracy/ [Accessed 20 April 2019].

Sanskriti, M. and Madhale, A. (2013) Participatory budgeting in Pune: A critical review. Unpublished report study. Pune: Amarnath Centre for Environment Education.

Shulga, I., Vagin, V., Sukhova, A., Khachatryan, G., Gavrilova, N., Shapovalova, N. and Shilov, L. (2017) Initiative budgeting. Russian experience of citizens' participation in addressing local issues. Moscow: Ministry of Finance of the Russian Federation and International Bank for Reconstruction and Development.

Sintomer, Y., Herzberg, C. and Röcke, A. (eds.) (2005) Participatory budgets in a European comparative approach. Düsserdolf: Hans Böckler Stiftung.

Sintomer, Y., Herzberg, C., Allegretti, G. in collaboration with Röcke, A. (2013) Participatory budgeting worldwide - updated version. No. 25 Dialog Global series. Bonn: Engagement Global.

Sobanjo, B. (2016) Strengthening participatory democracy through participatory budgeting. PhD Thesis. Minneapolis: Walden University.

The Nation. (2012) Participatory budgeting. Nation Online Malawi, 26 December 2012. Available at: https://mwnation.com/participatory-budgeting/ [Accessed 17 March 2019].

Thompson, N.K. (2012) Participatory budgeting - the Australian way. Journal of Public Deliberation, 8 (2), 5.

UCLG (2008) The 2nd global report on decentralization and local democracy. Barcelona: UCLG.

UCLG (2010) Local government finance: The challenges of the 21 st century. Barcelona: UCLG.

UN. (2015) Transforming our world: The 2030 Agenda for Sustainable Development. Available at: https://sustainabledevelopment.un.org/post2015/transformingourworld

V-Dem Institute. (2017) Measuring responsive, inclusive, participatory and representative decision-making at all levels in SDG Target 16.7 with V-Dem data. Policy Brief No \#10. Sweden: University of Gothenburg.

Verité Research. (2017) The local economic governance program: Notes for practitioners. Participatory planning and budgeting. The Asia Foundation. Available at: http://smartcity.sngpweb.com/wpcontent/uploads/2017/06/A-Practitioners-Note-on-Participatory-Budgeting-and-Planning-FINAL.pdf 